\title{
The homeless injection drug users and crack smokers in Montréal: different levels of attachment and uses of the place Émilie-Gamelin
}

Élaine Lesage-Mann and Philippe Apparicio

\section{(2) OpenEdition}

1 Journals

Electronic version

URL: https://journals.openedition.org/rfst/1340

DOI: $10.4000 /$ rfst. 1340

ISSN: 2492-3672

Publisher

Espaces et SOciétés (UMR 6590)

Electronic reference

Élaine Lesage-Mann and Philippe Apparicio, "The homeless injection drug users and crack smokers in Montréal: different levels of attachment and uses of the place Émilie-Gamelin", Revue francophone sur la santé et les territoires [Online], Varia, Online since 03 January 2022, connection on 09 January 2022. URL: http://journals.openedition.org/rfst/1340 ; DOI: https://doi.org/10.4000/rfst.1340

This text was automatically generated on 9 January 2022.



La Revue francophone sur la santé et les territoires est mise à disposition selon les termes de la Licence Creative Commons Attribution - Pas d'Utilisation Commerciale - Partage dans les Mêmes Conditions 4.0 International. 


\title{
The homeless injection drug users and crack smokers in Montréal: different levels of attachment and uses of the place Émilie-Gamelin
}

\author{
Élaine Lesage-Mann and Philippe Apparicio
}

\section{Background}

1 Homeless injection drug users and crack smokers are a highly mobile population for three main reasons. First, in order to meet their basic needs (mainly eat and sleep), they must move between the different resources. Secondly, their drug habits also require trips, whether to acquire their drugs and drug paraphernalia, but also to find a place they believe is suitable for consumption. Thirdly, another important aspect, not well documented in the literature, concerns the acquisition of financial resources. Indeed, given some of them can spend few hundreds of dollars a day to support their drug habits, those activities providing a much-needed income also generate many trips.

2 This population often use public spaces to meet these needs, for lack of other alternatives. Although there is a consensus in the literature on the crucial role of public spaces for drug users, to our knowledge, no study distinguishes their differentiated uses (both in terms of reasons and frequency of use). Few studies have also analyzed how mobility is organized around these public spaces, according to three types of needs (basic, drug habits and acquisition of financial resources). The aim of this study is to explore how homeless injection drug users or crack smokers use the Émilie-Gamelin place, a public space highly frequented by this population for several decades in Montréal. 


\section{Methods}

3 This descriptive qualitative study is based on grounded theory, in which two methods are used (i.e. participant observation, and semi-directive interviews). The participants were questioned about their daily mobility according to three main dimensions: basic needs, drug habits, and acquisition of financial resources. The questions in the interviews were formulated around the frequented locations, the frequency of these visits as well as the factors favouring or limiting them. We use two coding methods: a summary table for all the interviews and an in-depth thematic analysis conducted in the MAXQDA software.

\section{Findings}

4 The analysis of the coding results allowed us to classify the participants according to four types of public space uses. First, some homeless injection drug users or crack smokers are avoiding this space at all costs, generally because of bad experiences related to drug transactions or violence. Second, others use it as an occasional place of escape. This is a profile of users who are able to control their drug use habits (mainly crack smokers). They come specifically to Émilie-Gamelin place at a very variable frequency (from a few days per year to several days per month) when they feel the need to take drugs in order to escape. Third, many regularly visit Émilie-Gamelin place to take advantage of opportunities arising directly from its geographic location, but also from being frequented by many people, whether they are homeless or not. They come there to acquire financial resources but also to socialize and discuss with other homeless drug users. Fourth, Émilie-Gamelin place is the main living environment for many of them, some of whom rarely go more than 600 metres away. However, this is not always by choice, but because they have to or have nowhere to go. Some are with disabled mobility, others are excluded from resources and many no longer have any social or family support.

5 Our results show that the Émilie-Gamelin place is a very important anchoring point around which several homeless injection drug users and crack smokers organize their mobility. The analysis of their mobility (according to the three types of needs) also demonstrates how often it is constrained, that may have an important impact on their physical and mental health.

\section{Conclusion}

6 In light of our results, several dimensions deserve to be explored in more detail in order to better document the different uses, levels of attachment and forced mobility of the homeless injection drug users and crack smokers in Émilie-Gamelin place, notably in relation to drugs type, and especially gender. It is also clear that several factors contribute to the forced mobility for this population, mainly police repression, gentrification, and urban revitalization, which should also be analyzed in further work. 
Figure 1: Place Émilie-Gamelin during the summer season

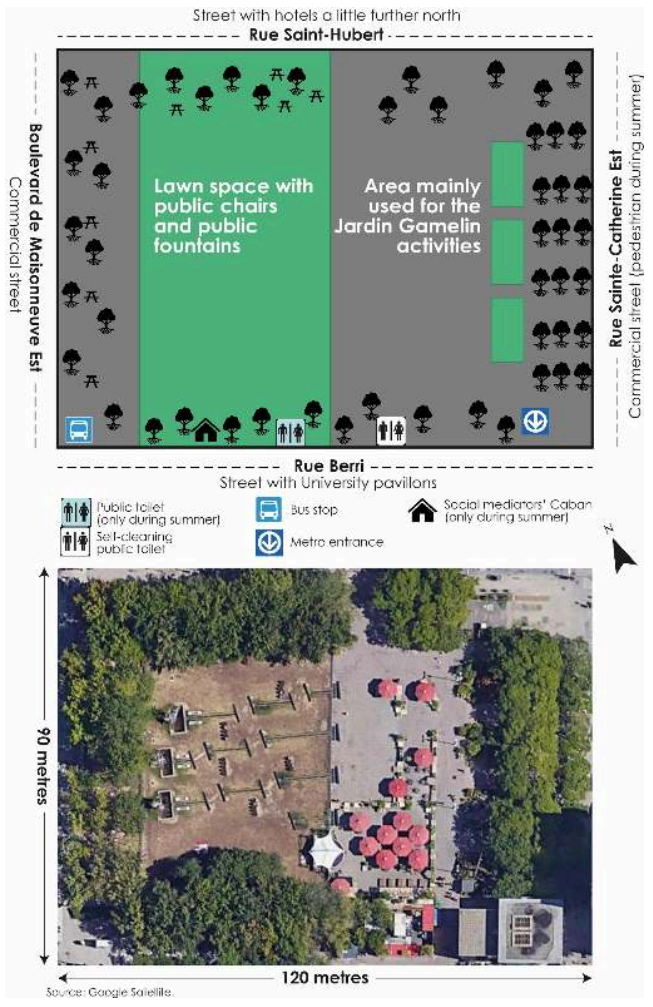

Figure 2: Services used by the injection drug users and crack smokers, located close to Place Émilie-Gamelin

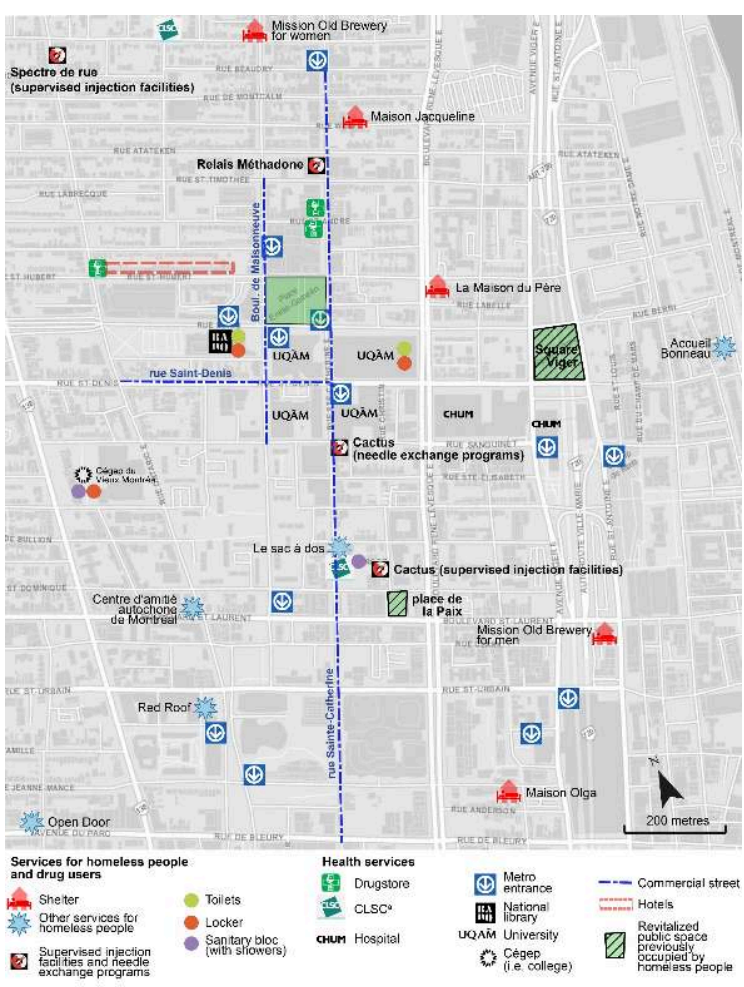


INDEX

Geographical index: Montréal

Keywords: homelessness, injection drug users and crack smokers, mobility

\section{AUTHORS}

\section{ÉLAINE LESAGE-MANN}

Institut national de la recherche scientifique, 385 rue Sherbrooke Est, Montréal (Québec), H2X 1E3, Canada

\section{PHILIPPE APPARICIO}

Institut national de la recherche scientifique, 385 rue Sherbrooke Est, Montréal (Québec), H2X 1E3, Canada 